Саша Д. Кнежевић

Универзитет у Источном Сарајеву

Филозофски факултет Пале

Катедра за србистику

e-mail: sasa.knezevic@ffuis.edu.ba

https://doi.org/10.18485/ai_san_o_gradu.2020.ch5

821.163.41.09:398(497.6)

Оригинални научни рад

\title{
ДВА БУМБУЛА СВУ НОЋ ПРЕПЈЕВАШЕ - САРАЈЕВО У СРПСКОЈ НАРОДНОЈ ЛИРИЦИ
}

У овом раду ћемо покушати одредити позицију Сарајева у српским лирским народним пјесмама, на примјеру пјесама из Вукове збирке, других референтних збирки из деветнаестог стољећа објављених у Сарајеву или сакупљених од самих Сарајлија и часописа Босанска вила. Покушаћемо одредити да ли се Сарајево јавља тек као топоним или сама чињеница да се оно у пјесми помиње у одређеној мјери детерминише и сам поетски састав.

Кључне ријечи: Сарајево, српска народна поезија, лирика, женске пјесме, Караџић, Петрановић, Хаџи-Ристић, Босанска вила

Чињеница да одредницу женске пјесме Вук не подређује родном статусу њихових извођача или слушалаца наглашава шири контекст у коме ова антрополошка класификација функционише, обухватајући узајамност супротстављених, али и комплементарних различитости универзума. Погрешно би, међутим, било закључити да се људска природа узима као апстрактна, непромјенљива категорија, отпорна на утицаје 
друштвено-историјског контекста. Вукова запажања у погледу родних дистинкција укључују и ареалне границе, менталитете и карактеролошке премисе: „Јуначке се пјесме данас највише и најживље пјевају по Босни и по Ерцеговини, и по Црној Гори и по јужним брдовитим крајевима Србије [...] Женски пак пјесама мислим да има највише амо доље (куд је мање јуначкије), и у Босни по варошима; јер како гођ су амо доље и људи мекши, тако су горе и жене (осим варошки) оштрије и више мисле о јунаштву, него о љубави; а може бити још и стога што амо доље, особито по Сријему и по Бачкој и по Банату, као и у Босни по варошима, жене и ђевојке живе више у друштву“ (Караџић1824: XIX).

Чињеница да Вук Караџић никада није користио књижевнотеоријске термине епско и лирско као одреднице уз одређене књижевне врсте потврђује колико је он био у праву када је пјесме именовао по суштинском животном принципу који је у њима заступљен: „Женске пјесме пјева једно или двоје само ради свога разговора, а јуначке се пјесме пјевају највише да други слушају; и зато се у пјевању женских пјесама више гледа на пјевање, него на пјесму, а у пјевању јуначкије највише на пјесму“ (1824: XVII). Истина, Љубомир Зуковић је (1985: 353) суштински у праву када за ову подјелу каже да „не треба превише озбиљно ни Вуково мишљење да се женске пјесме пјевају ради свога разговора, за разлику од јуначких, које се опет пјевају да би други слушали, јер су у суштини и једне и друге извођене и да би други слушали а и ради свога, односно извођачевог разговора“. Женске је, по правилу, Вуков термин за емоционално и фантастично, односно за женски принцип у свијету.

Вуково именовање, стога, заиста ваља сматрати и бољим и тачнијим од оног које преовладава у науч- 
ној терминологији, јер „Лирска народна песма, и по својим осталим особинама, често није чисто лирска, већ су емоције у њој посредоване сликом, ситуацијом, или фрагментарно испричаним догађајем. [...] Лирска народна песма, осим тога, обично и није само песма; она је, за разлику од уметничке (док се изводи у свом природном контексту), условљена обредом, обичајем, радом, не изводи се самостално и има практичну, прагматичну, намену“ (Карановић 2004: 5). Наиме, народна лирика се поетички не подудара са ауторском лириком, односно основне особине лирског израза ауторске поезије нису апсолутно примјењиве на народну поезију. Појмови којима се лирика примарно одликује као књижевни род, као што су субјективно, лично или индивидуално, смислено и значењски се потпуно друкчије исказују у народној лирици.

Народну лирску пјесму дефинише и аутентичан мизансцен, она је продукт неке уобичајене ситуације проистекле из општељудског искуства. Она пјева о свијету аутохтоне хармоније човјека са природом: „Народни песник као да још чини једно с природом око себе, још чује како цвеће расте, како се пиле леже из јајета, како се звезде множе. У његовој песми сама земља и сунце срце отворе и огласе се људским гласом“ (Попа 1958: 5). С друге стране, свој опстанак и трајање дугује исконској утопљености у свијест заједнице у којој настаје и која је пјева. Њена лирска, емоционална димензија, приказује се као свима разумљива и оштеприхватљива, кроз препознатљиве симболичне слике свијета. Отуда су њени јунаци или безимени или именовани уобичајеним, најчешће двосложним именима, Јово, Мара и сл. Они су јунаци неког догађаја исказаног у фрагменту којим се ипак, уз подразумијевана знања заједнице, исказује цјеловит смисао и поента. Једним фабулативним 
искораком оне прелазе у лирско-епске пјесме, стога се записани стихови, уз претпостављено читалачко искуство, јасно препознају као фрагмент неког дужег пјесничког састава (в. Кнежевић 2018: 11).

Вук Караџић није пјесме именовао ђевојачким, што је постало својеврсни манир његових сљедбеника, него женским, чега су се држали његови понајбољи настављачи, какав је био Богољуб Петрановић који ће своју књигу назвати Српске народне пјесме из Босне (женске). Прецизиравши како женске пјесме пјева једно или двоје само ради свога разговора, Караџић је недвосмислено нагласио интимност као основну особину њихову, исказану у опозицији спрам појашњења да се јуначке пјесме највише пјевају да други слушају. Ако се женске пјесме пјевају за себе и ради себе, природно је да у њима доминирају осјећања, поготово она прикривена и неизустива обичним ријечима, а којих, у табуима прекривеној патријархалној култури, засигурно није могло недостајати. Мада је и Вук наговијестио како женске пјесме понајприје пјевају ђевојке, али и момчад, што је заправо логично поготово кад се имају у виду митске парадигме највећег броја обредних пјесама, он ову групу није назвао „ђевојачке“ или „дјевојачке“, очигледно свјестан да је његовим именовањем закриљен знатно шири значењски слој. Дјевојаштво и све атрибуције које се уз њега културолошки везују само уз један слој женског архетипа, те стога и не чуди да се под женским пјесмама подразумијевају љубавне, породичне и посленичке пјесме, од којих су многе првобитну сакралност замијениле значењима артикулисаним у доцнијем, изванобредном контексту.

Усмени живот пјесама и подразумијевана динамика у времену и простору, заборављање и преосмишљавање, омогућили су њихове поетске метаморфозе, „све 
је у њој подложно промени“ (Недић 1969: 12). У условима изразите културолошке и вјерске подијељености, какви су одувијек били у Босни и Херцеговини, народне лирске пјесме су добијале своје бројне варијанте, усклађујући се према својим пјевачима и слушаоцима. Постојање веома сличних варијаната у којима су различита само имена јунака, недвосмислено потврђује ово основно начело усменопоетског стварања. Занимљив суд о том феномену изнио је један од најзначајнијих сакупљача са ових простора Коста Хаџи-Ристић (1873: 5) у Предговору скупиочевом своје пјесничке збирке: „Пјесама има и производнијех т. ј. да је једна од друге постала, а то из узрока што нијесу писане, него је један од другог чувши нешто придодавао или из заборави изостављао. Даље има пјесама које су пуне турских ријечи, а има их у којима нема ниједне стране ријечи. И томе има узрока т. j. гдје им је постанак, гдје су намишљене и.т.д.“. Ово нам показује да су сакупљачи као писмени и образовани људи суштински разумијевали варијантност као специфичност усменог израза и да су све пјесме које су се пјевале у њиховом крају сматрали дијелом локалне културе, без обзира на њихово могуће поријекло. Многе пјесме сакупљене у Босни и у Херцеговини током деветнаестог вијека имају варијанте у Вуковој збирци, што уз несумњив „повратни утицај“ штампаних збирки потврђује и суштинску монолитност патријархалних схватања и архаичних поимања свијета, као најважнију особину српске народне лирике.

Када се резимира Вуков сакупљачки рад, увијек се мора имати на уму да су његови ставови везани за Босну производ различитих информација из друге и треће руке, јер он никада за свога живота није ногом крочио на српски етнички простор западно од Дрине, због чега и сам жали. Сви његови пјевачи са ових про- 
стора, а било их је немало, и то изванредних, са Вуком су се сретали најчешће у Србији. Отуда је логично да је и он сам схватио да је највећи дио корпуса остао изван његове збирке и како је записивање српских народних пјесама из Босне и Херцеговине посао за друге људе и друга времена. У Вуковој збирци налази се већи број пјесама које је он „слушао и преписивао у Крагујевцу од неки (Турско -) Цигански ђевојака из Сарајева, као што и пјевају Српкиње турског закона у Сарајеву“ (Караџић 1824: XXXV), од који је пјесма Дјевојка се надмеће с момчетом (264), једина у групи Пјесме играчке, док су све остале сврстане у групу Љубавне и друге различне женске пјесме. За неколике пјесме сам Вук је у поднаслову написао сарајевска, мада се у њима Сарајево директно не помиње, а и Вук није објаснио на који је начин до њих дошао. У пјесмама обиљеженим словом Т Сарајево се експлицитно помиње у двије пјесме и то чисто узгредно, а у једној се у првом стиху помиње сарајевски топоним Бентбаша. У суштини, од свих пјесама са овом ознаком једина антологијска је Травник запаљен очима (659), нешто дужа и знатно боља варијанта од оне која је посредством Мокрањца стигла у антологије српске лирике.

Прилике нису ишле у прилог многобројним Вуковим сљедбеницима у Сарајеву све до 1867. године, када се у издању Босанско-вилајетске штампарије, као њено прво издање, појавила поменута Петрановићева збирка. Богољуб Петрановић није само по својим националним и романтичарским идејама био вуковац, него је статус Вуковог сљедбеника показао и при организацији садржаја својих збирки. Петрановић је 364 пјесме подијелио у девет група: Пјесме митологичке, Побожне пјесме, Божићне пјесме, Пјесме при успавтьвану, Пјесме жетеочке, Играчке пјесме, Пјесме сватовске, Пјесме о 
крсном имену и Љубавне и друге различне женске пјесме (в. Кнежевић 2018: 21). Оно што уочавамо у овом попису јесте одсуство обредних пјесама, које Зуковић (1985: 354) назива „избрушене магијске формуле“, а календарски круг представља тек осам божићних. То је карактеристика скоро свих штампаних збирки, као и пјесама прештампаних из часописа. Одсуство записа обредне лирике повезано је с чињеницом да је њих „условило бављење земљорадњом“ (Карановић 2004: 12), те су оне директно повезане с ритуалном радњом коју прате, па слабљење или нестајање обреда условљава и нестанак ових пјесама. Како сам Петрановић (1867: V) истиче, пјесме је већином сакупио „у Сарајеву и под Јаворином“, а обредне пјесме се примарно везују за село и аграрну заједницу, тако да и они који су их потенцијално раније пјевали у сеоској средини више нису имали прилике ни разлога да их пјевају у том облику. Заправо се и не ради о потпуном нестанку, него прије о функционалној трансформацији. Изван обредног контекста, пјесме су стицале статус љубавних, које су се могле пјевати у колу, на збору, сијелу или прелу, и сл. Љубавне пјесме и у овој збирци представљају више од двије трећине цјелокупног корпуса, а слично је и са осталим кориштеним издањима.

Петрановићева збирка је референтна и по томе што већ на почетку интензивног сакупљачког прегалаштва показује најзначајнију особину цјелокупне забиљежене грађе. Женске народне пјесме сакупљане у Босни, као и оне сакупљене по Херцеговини, јасно показују да не постоји значајнија поетичка специфичност која би их у већој мјери дистанцирала од свеукупног корпуса српске народне лирике. Потврђују, међутим, и Вуков став да се највише лирских пјесама очувало у градовима, будући да се у равни текста јасно може уочити 
њихова урбана амбијенталност. Овај став се ипак не може уопштити без остатка, јер ни у вријеме најинтензивнијег биљежења и објављивања сакупљачка активност није обухватала системска теренска истраживања, нити се на нивоу појединачне збирке инсистирало на равномјерној заступљености и репрезентативности. Немамо јасан увид шта је и како пјевано по селима, јер сакупљачи су или према властитим избору или према нужности чекали да пјесме дођу до њих, односно њихови извори су најчешће биле жене из њихове породице и ближе околине. Под утиском да „у ни једној вароши, гдје се српски говори, нема толико пјесама колико у Сaрајеву“, Богољуб Петрановић (1867: VI) није ни долазио у искушење да свој посао прошири на сеоску средину, па је у већ у Предговору прве најавио да ће „за кратко вријеме и другу књигу женскијех пјесама издати“ (1867: VIII). Петрановић (1867: VI) је на Вуковом трагу и кад каже: „Мало је читати народне пјесме, али је слађе и дивније слушати их пјевати: о свадби, о крсном имену, о божићу; у колу у пољу“, при чему нам оставља и занимљив етнографски податак о томе у каквим су се приликама у другој половини деветнаестог вијека у Сарајеву и његовој околини пјевале лирске народне пјесме. У потпуном сагласју са овим су и веома кратки Хаџи-Ристићев и Милановићев предговори, а и саме пјесме потврђују Петрановићеве ставове.

У часопису Босанска вила објављено је преко четири хиљаде народних пјесама од који је тек незнатан број епских. У том големом корпусу од градова се најчешће помињу Сарајево, Мостар и Бањалука. У више бројева забиљежене пјесме су именоване као сарајевске или из Сарајева. Велики број ових пјесама нема нарочит умјетнички квалитет и у великом броју се и не могу сматрати народним премда су објављене у чуве- 
ној рубрици Српске народне творевине. Ипак у броју 13-14. из 1901. године у овој рубрици, а са поднасловом Српске народне женске пјесме из Босне, проналазимо неколико иијелих тијепих пјесама у којима се Сарајево помиње у различитим облицима.
„Сарајево, дуго и широко,
Моје драго танко и високо;
Залуду је танко и високо
Кад мој бабо јорданџије не ће,
Који пали горкога дувана
Који пије вино и ракију,
Од дувана кућа попљувана
А од вина није кућа мирна
Од ракије кућа поплакује“ (БВ 1901: 247).

И иначе се Сарајево у лирским пјесмама најчешће јавља као урбоним, који се наравно мијења у различитим варијантама пјесме. Оваквих примјера налазимо у различитим облицима у антологији Лирске народне пјесме едиције Српска кюижевност у Босни и Хериеговини:

„Расла јела насред Сарајева,

На три стране разметнула гране“" (Кнежевић 2018: 219)

„У Сарај 'ву на новом пазару,

продаје се младо нежењено“ (Кнежевић 2018: 213)

„Бог т' убио граде Сарајево!

У тебе се љубе удовице

А не љубе лијепе ђевојке“ (Кнежевић 2018: 243).

Постоје наравно и праве сарајевске пјесме у којима се ради варијантности мора мијењати и текст пјесме, а не само име града попут ове из Ристићеве збирке: 
„Требевићу висока планино,

С тебе ми се види Сарајево

И сва села око Сарајева,

И мој драги свога коња вода

На глави му сјајна мјесечина.“ (Кнежевић 2018: 163)

У раније поменутом броју Босанске виле проналазимо још једну веома лијепу пјесму:

Коња јаше Нико Сарајлија,

Са камена на сред Сарајева,

Коло игра на сред Сарајева,

Коло стало, па Нику гледало,

Проговара Нико Сарајлија:

„Нисам дош`о голо застављати,

Већ сам дош`о гледати ђевојке,

Ја не гледам по грлу ђердана,

Ја не гледам по челу дуката,

Згодан бабо китио дукате,

Згодна мајка, китила ђердане,

Већ ја гледам смјерно и лијепо!“ (БВ 1901: 247-248)

У овој пјесми срећемо етник Сарајлија који је такође фреквентан у оба рода, као што проналазимо у примјеру:

„Платно б јели Сарајка дјевојка,

На Миљацки у златну леђену.

Засукала на руке рукаве

А на ноге црвене шарвале.

Бјеље су јој руке од рукава,

Црвеније ноге од шарвала.“ (БВ 1901: 248) 
У облику етника среће се и у пјесмама у којима је Сарајево дио андрићевског митског пута између Травника и Вишеграда ${ }^{1}$ :

„Караван иде преко Романије, За караваном Симо Сарајлија, А за њиме Стојко кириџија:

„Ој Бога ти, Симо Сарајлија, Јел слободно мало запјевати?“ „Ој Бога ти Стојко кириџија, Јест слободно колико ти драго!“

Тад запјева Стојко кириџија:

„Романијо, пуна ли си вука, Пуна вука и пуна хајдука,

А још више лијепих дјевојака!“ (Кнежевић 2018: 233)

Романија, која као колијевка хајдука представља симбол отвореног и слободног простора супротстављеног граду, опјевана је и у веома лијепој митолошкој пјесми из раније поменутог броја Босанске вите:

„Јово оре преко Романије,

Са соколом и с два вола плава.

Мајка Јови ручак донијела,

Кад јој Јове на орању нејма,

Приговара Јованова мајка:

„Ил` је Јову рало заорало,

Ил ' су Јову виле однијеле?“

Проговара нешто из планине:

„Није Јову рало заорало,

Већ су Јову виле премамиле.“ (БВ 1901: 247)

На овом примјеру видимо да су српске народне

1 О овоме више видјети у раду Романија - митски простор Андрићеве прозе. 
лирске пјесме у Босни паралелно живјеле у двије струје. Прва је чаршијска или варошка и спецификује је особена урбална амбијенталност, те су самим тиме по правилу љубавне и друга која се пјева изван градских капија, изван неслободе коју град сам по себи твори и у којима је као доминанта црта очувано паганско осјећање живота, које је Владан Недић (1969: 13) детерминисао као „Главно обележје наше народне лирике“. Када женске пјесме заживе у градској средини оне се прекодирају у љубавне или шаљиве, за шта није изнимка ни „шехер-Сарајево“ чак ни кад се на њега погледује с Требевића „високе планине“ или с небеса као соко који „лети преко Сарајева“. Примјери нам показују да се у већини случајева Сарајево помиње као промјењива варијабла варијаната забиљежених у њему, што потврђује Петрановићеву тезу о бројности народних пјесама које су се у овом граду у његово вријеме у и о њему пјевале на српском језику.

\section{Литература}

Зуковић, Љубомир. О нашем усменом песништву. Сарајево: Свјетлост, 1985. Штампано.

Караџић, Вук. Народне српске пјесме - книга прва. Лајпциг: Штампарија Брајткопфа и Ертла, 1824. Штампано.

Кнежевић, Саша. „Романија - митски простор Андрићеве прозе“, Нова зора бр. 35-36 (2013), 349-352. Штампано.

Кнежевић, Саша. Лирске народне пјесме. Бањалука: Друштво чланова Матице српске у Републици српској, 2018. Штампано.

Милановић, М. Српске народне женске пјесме из Сарајева, Сарајево, 1893. Штампано.

Недић, Владан. Југословенска народна лирика. Београд: Српска књижевна задруга, 1969. Штампано. 
Петрановић, Богољуб. Српске народне пјесме из Босне (женске). Сарајево: Босанска вилајетска штампарија, 1867. Штампано.

Попа, Васко. Од злата јабука. Београд: Нолит, 1958. Штампано.

Хаџи-Ристић, Коста. Српске народне пјесме - покупљене по Босни, Београд, 1873. Штампано.

БB. Bosanska vila 1885 - 1914. Sarajevo. DVD.

Saša Knežević

\section{ZWEI BUMBUL SICH DIE GANZE NACHT VOR - SARAJEVO IN DEN SERBISCHEN NATIONALEN LYRICS}

\section{Zusammenfassung}

In diesem Artikel versuchen wir, Sarajevos Position in serbischen lyrischen Volksliedern zu bestimmen, zum Beispiel Gedichte aus der Sammlung von Vuk, aus anderen in Sarajevo veröffentlichten Referenzsammlungen des 19. Jahrhunderts oder von den Sarajevos selbst und dem Magazin Bosnian Fair. Wir werden versuchen festzustellen, ob Sarajevo nur als Toponym auftritt oder ob die Tatsache, dass es in dem Gedicht erwähnt wird, in gewissem Maße die poetische Komposition selbst bestimmt.

Schlüsselwörter: Sarajevo, serbischen lyrischen, Karadžić, Petranović, Hadži-Ristić, Bosanska vila. 